\title{
STRATEGI PEMBELAJARAN BAHASA ARAB DENGAN \\ PENDEKATAN KONTEKSTUAL UNTUK MENINGKATKAN \\ KETERAMPILAN MENULIS SISWA KELAS XI SMK \\ DIPONEGORO TUMPANG MALANG
}

\section{OLEH: TAUFIQ ANSHORI}

E-mail taufiq86anshori@gmail.com

\begin{abstract}
ABSTRAK
Taufiq Anshori. 2016. Strategi Pembelajaran Bahasa Arab Dengan Pendekatan Kontekstual Untuk Meningkatkan Keterampilan Menulis Pada Siswa Kelas XI SMK Diponegoro Tumpang Malang.
\end{abstract}

Kata Kunci: Keterampilan Menulis Bahasa Arab, Strategi pembelajaran dengan Pendekatan Kontekstual.

Kegiatan menulis khususnya bahasa Arab, adalah salah satu kompetensi dasar yang termasuk dalam empat keterampilan aspek kebahasaan. Kompetensi tersebut harus dikuasai oleh siswa kelas XI SMK Diponegoro Tumpang Malang. Untuk mencapai hal tersebut, perlu adanya strategi pembelajaran yang tepat. Berdasarkan hasil observasi awal, di kelas XI SMK Diponegoro Tumpang Malang, menunjukkan bahwa dalam mengikuti pembelajaran keterampilan menulis bahasa Arab banyak yang belum dapat menguasai dengan baik dan benar mengenai materi yang telah diajarkan, dan sikap siswa yang kurang tertarik dengan pembelajaran keterampilan menulis bahasa Arab. Disamping itu, kurangnya usaha guru dalam memotivasi peserta didiknya untuk menulis bahasa Arab dan model pembelajaran yang digunakan secara konvensional yaitu dengan menghafal, gramatikal-terjemah bahkan ceramah. Sehingga siswa merasa bosan dan menjadi pasif. Oleh sebab itu, pemilihan strategi pembelajaran dengan pendekatan kontekstual merupakan upaya untuk meningkatkan keterampilan menulis bahasa Arab siswa kelas XI SMK Diponegoro Tumpang Malang.

Rumusan masalah dalam penelitian ini adalah: (1) Bagaimana aplikasi pembelajaran bahasa Arab pada siswa kelas XI SMK Diponegoro Tumpang Malang.

(2) Bagaimana strategi pembelajaran bahasa Arab dengan pendekatan Kontekstual pada siswa kelas XI SMK Diponegoro Tumpang Malang. (3) Bagaimana pendekatan kontekstual dalam pembelajaran bahasa Arab untuk meningkatkan keterampilan menulis pada siswa kelas XI SMK Diponegoro 
Tumpang Malang. Tujuan dari penelitian ini adalah (1) Untuk mengetahui pendekatan kontekstual dalam pembelajaran bahasa Arab pada siswa kelas XI SMK Diponegoro Tumpang Malang.

(2) Untuk mengetahui strategi pembelajaran bahasa Arab dengan pendekatan kontekstual dalam pembelajaran untuk pada siswa kelas XI Smk Diponegoro Tumpang Malang. (3) Untuk mengetahui aplikasi pembelajaran bahasa Arab dengan pendekatan kontekstual pada kelas XI SMK Diponegoro Tumpang Malang. (4) Untuk mengetahui peningkatan keterampilan menulis bahasa Arab dengan pendekatan kontekstual pada siswa kelas XI SMK Diponegoro Tumpang Malang.

Metode penelitian yang digunakan adalah penelitian tindakan kelas yang dirancang dalam dua siklus. Instrumen yang digunakan adalah instrumen tes dan nontes. Teknik pengumpulan data menggunakan tes dan nontes. Teknik analisis data berupa analisis deskriptif kualitatif dan analisis deskriptif prosentase.

Hasil penelitian ini menunjukkan adanya peningkatan dari siklus I ke siklus II. Dari data tes dapat diketahui peningkatan yaitu skor rata- rata kelas dari 39 siswa pada siklus I adalah 52,67 dan pada siklus II adalah 66,56. Dapat diketahui bahwa terjadi peningkatan hasil belajar subjek penelitian dari tiap pertemuan. Dalam prosentase peningkatan tersebut adalah $26,37 \%$ dari pertemuan I ke pertemuan II. Dan terjadi peningkatan sebesar 3,61\% dari pertemuan II ke pertemuan III. Selanjutnya peningkatan $9.06 \%$ dari pertemuan III ke pertemuan IV. Berdasarkan penelitian yang dilakukan, diperoleh hasil bahwa peningkatan keterampilan menulis bahasa Arab melalui strategi pembelajaran dengan pendekatan kontekstual pada siswa kelas XI SMK Diponegoro Tumpang Malang dari siklus I ke siklus II adalah sebesar 13,01\%. Hasil analisis data nontes juga menunjukkan adanya perubahan perilaku siswa kelas XI SMK Diponegoro Tumpang Malang. 